\title{
Phenolic composition and cell-based biological activities of ten coloured potato peels (Solanum tuberosum L.)
}

\author{
Shirley L. Sampaio ${ }^{\text {a,b }}$, Spyridon A. Petropoulos ${ }^{c}$, Maria Inês Dias ${ }^{\text {a, }}$, Carla Pereira ${ }^{\text {a }}$, \\ Ricardo C. Calhelha ${ }^{a}$, Ângela Fernandes ${ }^{a}$, Camila M.M. Leme ${ }^{a}$, Alexios Alexopoulos ${ }^{\mathrm{d}}$, \\ Celestino Santos-Buelga ${ }^{b}$, Isabel C.F.R. Ferreira ${ }^{a}$, Lillian Barros ${ }^{\text {a, }}$ \\ ${ }^{a}$ Centro de Investigação de Montanha (CIMO), Instituto Politécnico de Bragança, Campus de Santa Apolónia, 5300-253 Bragança, Portugal \\ ${ }^{\mathrm{b}}$ Grupo de Investigación en Polifenoles (GIP-USAL), Facultad de Farmacia, Universidad de Salamanca, Campus Miguel de Unamuno s/n, 37007 Salamanca, Spain \\ ${ }^{\mathrm{c}}$ University of Thessaly, Department of Agriculture, Crop Production and Rural Environment, 38446 N. Ionia, Magnissia, Greece \\ ${ }^{\mathrm{d}}$ University of the Peloponnese, Department of Agriculture, 24100 Kalamata, Greece
}

\section{A R T I C L E I N F O}

\section{Keywords:}

Potato peels

Solanum tuberosum L.

Non-anthocyanin phenolics

Anthocyanins

Antioxidant activity

Antitumor activity

Anti-inflammatory activity

\begin{abstract}
A B S T R A C T
The present study provides an in-depth characterisation of the non-anthocyanin and anthocyanin phenolic compounds of potato peels from ten coloured potato varieties. Furthermore, the underexplored bioactive potential (antioxidant, cytotoxic and anti-inflammatory capacities) of the studied peels is comprehensively analysed. Among non-anthocyanin phenolics, caffeic and a caffeoylquinic acid were found in the highest concentrations in all samples, which also showed the presence of $O$-glycosylated flavonol derivatives and polyamine derivatives. Acylated anthocyanins were identified in red and purple varieties, being pelargonidin, peonidin, and malvidin the most prominent aglycones. All samples revealed antioxidant and antitumor activities, and no toxic effect. The extract of the Rosemary variety presented the best antioxidant and antitumor outcomes and was the only sample to reveal anti-inflammatory activity. These results are valuable for the food-industry by adding value to an important bio-residue, particularly concerning its potential as natural ingredients in novel food and pharmaceutical formulations.
\end{abstract}

\section{Introduction}

The food and pharmaceutical industries have been intensively researching the use of natural matrices as sources of bioactive compounds to find alternatives for synthetic food additives and drugs. At the same time, the valorisation of bio-residues rich in bioactive compounds that are usually discarded, such as potato peels, could contribute to the creation of more economically and socially sustainable productive chains in the agro-industry sector (Pathak, Mandavgane, Puranik, Jambhulkar, \& Kulkarni, 2018; Sampaio, Petropoulos et al., 2020).

Potato (Solanum tuberosum L.) is the most important vegetable crop, with more than 5000 known varieties, a global production of around 368 million tonnes and one of the largest food processing sectors throughout the world (Sampaio, Petropoulos et al., 2020). Peeling is usually the first step in the processing chain of raw tubers into added value food products, such as crisps, chips, mashed potatoes and frozen products (Pathak et al., 2018). This processing step results in the generation of a great amount of bulky waste (15-40\% of the original fresh weight depending on the processing procedure) that is usually discarded or used as low value animal feed (Schieber, Stintzing, \& Carle, 2002). Annually, between 70 and 140 thousand tonnes of potato peels are generated worldwide (Hossain, Rawson, Aguiló-aguayo, Brunton, \& Rai, 2015). Therefore, up-grading of this bio-residue to added value products could decrease the overall environmental impacts of the potato processing industry and add value to this production chain (Sampaio, Petropoulos et al., 2020).

Potato peels are rich sources of phytochemicals with known biological activities, such as phenolic acids and flavonoids. Moreover, purple-fleshed potatoes are rich sources of anthocyanins, and the amounts stored in peels are usually higher than the flesh when both flesh and peels are coloured (Chaves-Silva et al., 2018). Previous studies have highlighted the bioactive potential of potato peel extracts, for instance their antioxidant (Jeddou et al., 2018; Singh et al., 2011; Singh \& Rajini, 2004; Yin et al., 2016), anti-inflammatory (Wahyudi, Ramadhan,

\footnotetext{
* Corresponding authors.

E-mail addresses: maria.ines@ipb.pt (M.I. Dias), lillian@ipb.pt (L. Barros).
} 
Wijaya, Ardhani, \& Utami, 2020), antimicrobial (Juneja, Friedman, Mohr, Silverman, \& Mukhopadhyay, 2018) and anticancer properties (Reddivari, Vanamala, Chintharlapalli, Safe, \& Miller, 2007).

In this study, an in-depth characterisation of the phenolic composition of potato peels was performed, obtained from ten red and purpleskinned varieties from five different countries of origin (Chile, Germany, Austria, United Kingdom and Finland). Furthermore, a comprehensive analysis of the underexplored bioactive potential of the studied peels was carried out, by assessing their antioxidant, cytotoxic and antiinflammatory capacities. This work aims to provide valuable information that will support the valorisation of an important food processing industry bio-residue, particularly concerning its underexplored potential as a natural additive for application into functional food formulations. At the same time the presented information could help to alleviate the environmental burden that potato processing generates and increase the added value of this economically important crop.

\section{Materials and methods}

\subsection{Plant material production and processing}

Red- and purple-skinned potato tubers (Solanum tuberosum L.) of ten genotypes (Red-skinned: Rosemary, Red Emmalie, Red Cardinal; Purpleskinned: Purple, Violetta, Kefermarkter Blaue, Salad Blue, Blaue aus Finnland, UACH 0917 and Shetland Black) from five different countries of origin (Chile, Germany, Austria, United Kingdom and Finland) were cultivated in the experimental farm of the University of Thessaly in Velestino, Greece (Table 1). Fresh harvested tubers of uniform size, depending on the prevalent size for each genotype, were transported to the Polytechnic Institute of Bragança, Portugal, where the samples were washed with cold tap water upon arrival to eliminate extraneous matter. In particular, tubers' mean size for each genotype was as follows: Rosemary (53.5 g), Red Emmalie (108.6 g), Red Cardinal (58.5 g); Purpleskinned: Purple (145.0 g), Violetta (49.6 g), Kefermarkter Blaue (60.5 g), Salad Blue (130.3 g), Blaue aus Finnland (59.1 g), UACH 0917 (70.3 g) and Shetland Black (45.6 g). A colour assessment of the samples was carried out before the peels were manually separated from the flesh, using a Minolta spectrophotometer (model CR-400; Konica Minolta Sensing, Inc., Japan) using illuminant $C$ and a measuring aperture of 8 $\mathrm{mm}$. The $L^{*}, a^{*}$ and $b^{*}$ CIELab colour values were measured through the computerized system. The peel samples were then freeze-dried $\left(-49^{\circ} \mathrm{C}\right.$, 0.08 bar, during 48 h, FreeZone 4.5 model 7750031, Labconco, Kansas, USA) and reduced to a fine and homogeneous powder.

\subsection{Extracts preparation}

The powdered freeze-dried peels were extracted twice with ethanol: water $(80: 20 \mathrm{v} / \mathrm{v})$ under stirring for $1 \mathrm{~h}$ and filtered (Whatman paper No. 4). The obtained solutions were evaporated under reduced pressure at $40{ }^{\circ} \mathrm{C}$ (rotary evaporator Büchi R-210, Flawil, Switzerland) until the total removal of the solvent. The obtained extracts were then freezedried. The freeze-dried extracts were dissolved in a hydroethanolic solution 80:20 $(v / v)$ and filtered through a $0.22 \mu \mathrm{m}$ nylon filter, followed by immediate characterization.

\subsection{Non-anthocyanin and anthocyanin phenolic compounds characterisation}

The ten extracts were characterised by high performance liquid chromatography (Dionex Ultimate 3000 UPLC, Thermo Fisher Scientific, San Jose, CA, USA) using the conditions previously described by the authors (Albuquerque et al., 2020). The compounds detection was performed using a diode-array detector linked to an electrospray ionization mass spectrophotometer (Linear Ion Trap LTQ XL, Thermo Scientific, San Jose, CA, USA). The preferred wavelengths used were 280, 330 and $370 \mathrm{~nm}$, for non-anthocyanin compounds, and $520 \mathrm{~nm}$ for anthocyanins.
Data collection and analysis was carried out using the Xcalibur ${ }^{\circledR}$ program (Thermo Fisher Scientific, San Jose, CA, USA). The identification of the phenolic molecules was performed based on their retention time, UV-vis spectra, mass characteristics and literature data. The quantification of the compounds was performed using 7-level calibration curves and the results were expressed as mg per $g$ of dry weight (dw).

\subsection{Biological activities evaluation}

\subsubsection{Cell-based antioxidant activity (TBARS and OxHLIA)}

The antioxidant activity of the obtained extracts was assessed in terms of their potential to inhibit the production of thiobarbituric acid reactive substances (TBARS) in porcine (Sus scrofa) brain homogenates, a cell-based in vitro method described in detail by Corrêa et al. (2015). The results were expressed as IC $_{50}$ values, which correspond to the extract concentration that provides $50 \%$ of antioxidant activity $(\mu \mathrm{g} / \mathrm{ml})$. For the oxidative haemolysis inhibition assay (OxHLIA), a cell-based method described by Garcia et al. (2019) was followed. The results were also expressed as $\mathrm{IC}_{50}$ values $(\mu \mathrm{g} / \mathrm{mL})$, which correspond to the extract concentration able to promote a $\Delta \mathrm{t}$ haemolysis delay of $60 \mathrm{~min}$. Trolox was used as positive control in both methods.

\subsubsection{Anti-inflammatory activity}

The anti-inflammatory activity of the extracts was evaluated by lipopolysaccharide (LPS)-induced nitric oxide (NO) production by mouse macrophages RAW 264.7, a procedure described in detail by Corrêa et al. (2015). Dexamethasone $(50 \mu \mathrm{M})$ was used as positive control, and a negative control was prepared without the addition of LPS to observe possible effects on the basal levels of NO. The results were expressed as $\mathrm{IC}_{50}$ values $(\mu \mathrm{g} / \mathrm{mL})$, which correspond to the extract concentration that induced $50 \%$ of inhibition of NO production.

\subsubsection{Anti-proliferative activity and cytotoxicity}

The anti-proliferative activity of the hydroethanolic extracts was evaluated using four human tumour cell lines: NCI-H460 (lung carcinoma); MCF-7 (breast carcinoma); HepG2 (hepatocellular carcinoma); and HeLa (cervical carcinoma), according to the method described by Albuquerque et al. (2020). The results were expressed as $\mathrm{GI}_{50}$ values $(\mu \mathrm{g} / \mathrm{mL})$, which correspond to the extract concentration capable of inhibit $50 \%$ of cell proliferation.

In order to study the extracts safety and potential to be used as additives in food formulations, a cytotoxicity assay was carried out. A primary culture of non-tumour liver cells obtained from porcine liver (PLP2) was used, following the procedure previously described by the authors (Sampaio, Fernandes et al., 2020). The results were expressed as $\mathrm{GI}_{50}$ values, which correspond to the extract concentration capable of inhibit $50 \%$ of the net cell growth, and ellipticine (Sigma-Aldrich, St Louis, MO, USA) was used as a positive control.

\subsection{Statistical analysis}

Three samples were used for each assay. All assays were carried out in triplicate. The results were analysed using one-way analysis of variance (ANOVA) followed by Tukey's HSD Test with $p=0.05$ and were expressed as mean values with standard deviations (SD).

\section{Results and discussion}

\subsection{Colour assessment}

A quantitative analysis of the outer colour of the tested potato peels was carried out. The results for the Hunter colour parameters $L^{*}$ (lightness), $a^{*}$ (green-redness) and $b^{*}$ (blue-yellowness) are presented in Table 1 . The three red-skinned varieties presented the highest values for the parameter $a^{*}$ as expected, quantitatively confirming the presence of red tones in the peels (Rosemary: 24.8, Red Emmalie: 24.4 and Red 
Table 1

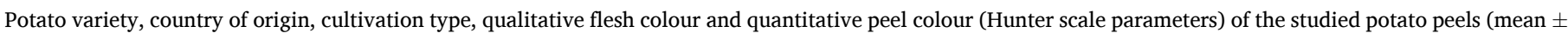
$\mathrm{SD)}$.

\begin{tabular}{|c|c|c|c|c|c|c|}
\hline \multirow[t]{2}{*}{ Potato variety } & \multirow{2}{*}{$\begin{array}{l}\text { Country of } \\
\text { origin }\end{array}$} & \multirow{2}{*}{$\begin{array}{l}\text { Cultivation } \\
\text { type }\end{array}$} & \multirow[t]{2}{*}{ Flesh colour } & \multicolumn{3}{|c|}{ Peel colour } \\
\hline & & & & $L^{*}$ & $a^{*}$ & $b^{*}$ \\
\hline Rosemary & Germany & $\begin{array}{l}\text { Cultivated } \\
\text { variety }\end{array}$ & Red & $41 \pm 1^{b}$ & $\begin{array}{l}24.8 \pm \\
0.4^{\mathrm{a}}\end{array}$ & $\begin{array}{l}10.1 \pm \\
0.4^{\mathrm{c}}\end{array}$ \\
\hline Red Cardinal & $\begin{array}{l}\text { United } \\
\text { Kingdom }\end{array}$ & Landrace & Red & $41 \pm 2^{\mathrm{b}}$ & $\begin{array}{l}20.1 \pm \\
0.7^{\mathrm{b}}\end{array}$ & $\begin{array}{l}11.2 \pm \\
0.2^{\mathrm{b}}\end{array}$ \\
\hline $\begin{array}{l}\text { Rote Emmalie (Red } \\
\text { Emmalie) }\end{array}$ & Germany & $\begin{array}{l}\text { Cultivated } \\
\text { variety }\end{array}$ & Red & $38 \pm 2^{c}$ & $\begin{array}{l}24.4 \pm \\
0.5^{\mathrm{a}}\end{array}$ & $\begin{array}{l}8.7 \pm \\
0.7^{\mathrm{d}}\end{array}$ \\
\hline Purple & - & - & Purple & $\begin{array}{l}27.3 \pm \\
0.9^{f}\end{array}$ & $\begin{array}{l}6.3 \pm \\
0.7^{\mathrm{e}}\end{array}$ & $\begin{array}{l}3.0 \pm \\
0.7^{f, g}\end{array}$ \\
\hline Kefermarkter Blaue & Austria & Landrace & Purple & $\begin{array}{l}31.2 \pm \\
0.5^{\mathrm{d}}\end{array}$ & $\begin{array}{l}7.3 \pm \\
0.3^{\mathrm{d}}\end{array}$ & $\begin{array}{l}3.3 \pm \\
0.3^{f, g}\end{array}$ \\
\hline UACH 0917 & Chile & $\begin{array}{l}\text { Andean } \\
\text { accession }\end{array}$ & Purple & $\begin{array}{l}28.4 \pm \\
0.1^{\mathrm{e}}\end{array}$ & $\begin{array}{l}4.0 \pm \\
0.6^{\mathrm{f}}\end{array}$ & $\begin{array}{l}1.6 \pm \\
0.2^{\mathrm{h}}\end{array}$ \\
\hline Salad Blue & $\begin{array}{l}\text { United } \\
\text { Kingdom }\end{array}$ & $\begin{array}{l}\text { Cultivated } \\
\text { variety }\end{array}$ & Purple & $\begin{array}{l}29.0 \pm \\
0.4^{\mathrm{e}}\end{array}$ & $\begin{array}{l}5.9 \pm \\
0.5^{\mathrm{e}}\end{array}$ & $\begin{array}{l}2.48 \pm \\
0.2^{g, h}\end{array}$ \\
\hline Blaue aus Finnland & Finland & Landrace & Purple & $\begin{array}{l}28.8 \pm \\
0.6^{\mathrm{e}}\end{array}$ & $\begin{array}{l}5.3 \pm \\
0.2^{\mathrm{e}}\end{array}$ & $4.1 \pm 0.9^{f}$ \\
\hline $\begin{array}{l}\text { Shetland Black } \\
\text { (Ellenb.) }\end{array}$ & $\begin{array}{l}\text { United } \\
\text { Kingdom }\end{array}$ & $\begin{array}{l}\text { Cultivated } \\
\text { variety }\end{array}$ & $\begin{array}{l}\text { Marble (purple/ } \\
\text { yellow) }\end{array}$ & $46 \pm 1^{\mathrm{a}}$ & $\begin{array}{l}9.1 \pm \\
0.6^{\mathrm{c}}\end{array}$ & $18 \pm 2^{\mathrm{a}}$ \\
\hline
\end{tabular}


Table 1 (continued)

\begin{tabular}{|c|c|c|c|c|c|c|}
\hline \multirow[t]{2}{*}{ Potato variety } & \multirow{2}{*}{$\begin{array}{l}\text { Country of } \\
\text { origin }\end{array}$} & \multirow{2}{*}{$\begin{array}{l}\text { Cultivation } \\
\text { type }\end{array}$} & \multirow[t]{2}{*}{ Flesh colour } & \multicolumn{3}{|c|}{ Peel colour } \\
\hline & & & & $L^{*}$ & $a^{*}$ & $b^{*}$ \\
\hline Violetta (Blaue Elise) & Germany & $\begin{array}{l}\text { Cultivated } \\
\text { variety }\end{array}$ & Purple & $32 \pm 2^{\mathrm{d}}$ & $\begin{array}{l}1.6 \pm \\
0.2^{g}\end{array}$ & $6.1 \pm 0.7^{\mathrm{e}}$ \\
\hline
\end{tabular}

In each column different Latin letters are significantly different according to Tukey's HSD test $(p=0.05)$, for each potato group peels.

Cardinal: 20.7). The peels from these three varieties also presented the highest values for $b^{*}$ (Rosemary: 10.1, Red Emmalie: 8.7 and Red Cardinal: 11.2), after only the marble (purple/yellow) variety Shetland Black, which presented the highest $b$ * values (18) among all the tested varieties. This finding indicates that for this variety the presence of yellow tones was more prominent than blue tones. The purple varieties, in turn, presented the lowest values for $b^{*}$, a result which is associated to the presence of blue tones in the peels. The Shetland Black variety also presented the highest values for $L^{*}$, meaning its peel had the lightest colour among the ten varieties. Significant differences in skin colour parameters among various potato cultivars have been also reported by Seijo-Rodríguez et al. (2018), while Yang \& Achaerandio (2015) and

Table 2

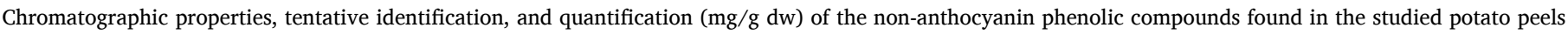
(mean $\pm \mathrm{SD}$ ).

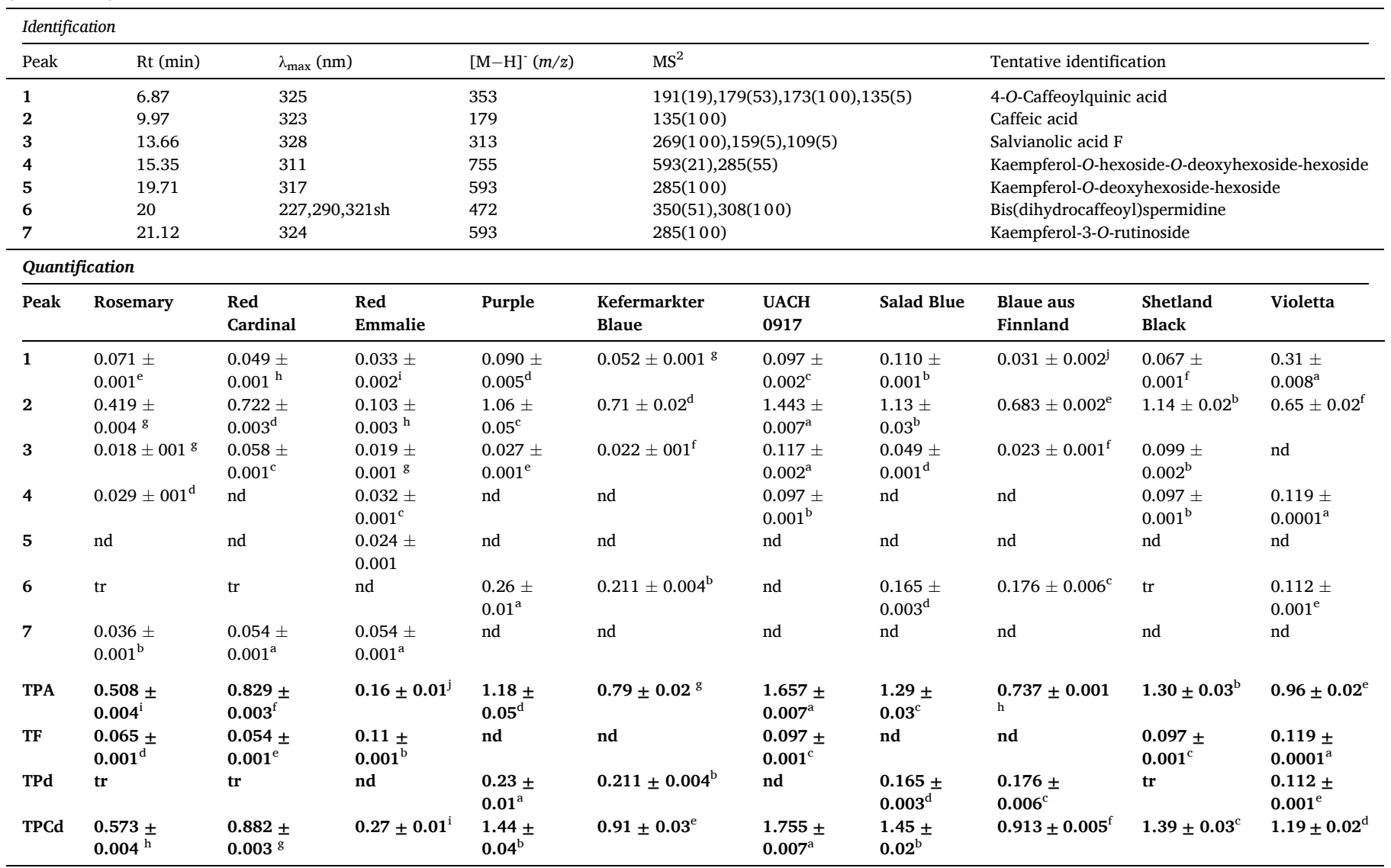

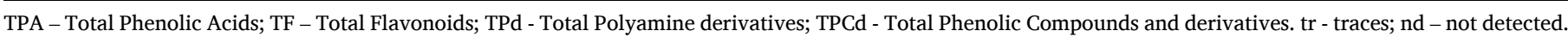

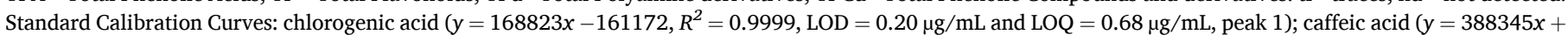

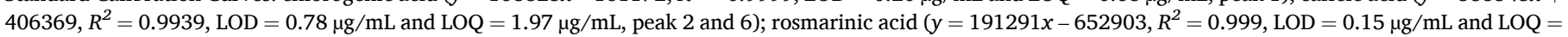

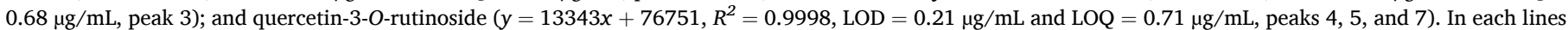
different Latin letters are significantly different according to Tukey's HSD test $(p=0.05)$, for each potato group peels. 
Cabezas-Serrano et al. (2009) suggested that colour parameters can be affected by pre- and post-harvest factors, as well as by the genotype.

\subsection{Phenolic compounds characterisation}

\subsubsection{Non-anthocyanin phenolics}

The profiles of non-anthocyanin phenolic derivatives in the tested potato peels, including chromatographic characteristics, tentative identities and quantification are shown in Table 2. Seven compounds were detected, of which three were tentatively identified as phenolic acid derivatives, three as flavonol glycosides and one as a caffeoylpolyamine derivative, based on the observation of their absorption spectra, pseudomolecular ion, characteristic $\mathrm{MS}^{2}$ fragments and literature data (Barros et al., 2013a, 2013b; Choi, Kozukue, Kim, \& Friedman, 2016; Friedman, Kozukue, Kim, Choi, \& Mizuno, 2017; Rommens et al., 2008; Svobodova et al., 2017; Yang, Wu, Rui, Guo, \& Feng, 2015).

Peaks 1-3 were tentatively identified as phenolic acids. Peak 1 $\left([\mathrm{M}-\mathrm{H}]^{-}\right.$at $\left.m / z 353\right)$ was detected in all the tested potato peels and tentatively identified as 4-O-caffeoylquinic acid, i.e., the ester formed between caffeic acid and the 4-hydroxyl of L-quinic acid (Svobodova et al., 2017). Peak $2\left([\mathrm{M}-\mathrm{H}]^{-}\right.$at $m / z$ 179) was the most abundant compound in all the tested varieties, with concentrations ranging from 0.42 (Rosemary) to 1.44 (UACH 0917) $\mathrm{mg} / \mathrm{g} \mathrm{dw}$, being identified as caffeic acid by comparison with retention time, UV-vis, and chromatographic characteristics of the available commercial standard compound. Peak $3\left([\mathrm{M}-\mathrm{H}]^{-}\right.$at $\left.m / z 313\right)$ was identified as salvianolic acid F, based on its $\mathrm{MS}^{2}$ fragmentation as previously reported in the literature (Barros et al., 2013a, 2013b; Yang et al., 2015). Peaks 4, 5 and 7 were identified as flavonols, all of which being kaempferol derivatives, after comparing the obtained LC-MS data with those reported by other authors (Rommens et al., 2008; Svobodova et al., 2017); their glycosylation patterns were assigned based on the pseudomolecular ions and mass fragmentation profiles. Finally, Peak $6\left([\mathrm{M}-\mathrm{H}]^{-}\right.$at $m / z$ 472) was only detected in five purple-skinned varieties (Purple, Kefermarkter Blaue, Salad Blue, Blaue aus Finnland and Violetta) and was tentatively identified as bis(dihydrocaffeoyl) spermidine, a polyamine derivative, previously described by Svobodova et al. (2017) in the non-edible parts of Solanum stramoniifolium Jacq. This polyamine derivative was described as a potent oxidative inhibitor (Ponasik et al., 1995), and it is also used as a molecular marker for the authentication of the origin of several potato varieties from Italy (Adamo et al., 2012). The concentration of total phenolic compounds and derivatives among the peels of the studied potato varieties showed a great variation and ranged from 0.27 (Red Emmalie) to 1.76 (UACH 0917) $\mathrm{mg} / \mathrm{g}$ dw. In accordance with our results, literature data show that the total amount of phenolic compounds in potato peels can vary significantly among different varieties (Sampaio, Petropoulos et al., 2020; Torres et al., 2020), while the processing treatment and extraction method may also have an effect on the content of phenolic compounds (Camire, Kubow, \& Donelly, 2009).

\subsubsection{Anthocyanins}

The anthocyanins profile, chromatographic characteristics, tentative identifications, and quantifications for the red- and purple-skinned varieties are shown in Tables 3 and 4, respectively. All tentatively identified compounds were previously described in the literature (Kita, Bakowska-Barczak, Hamouz, Kułakowska, \& Lisińska, 2013; Oertel et al., 2017; Su et al., 2016), and identified as acylated anthocyanins, owing to the presence of a shoulder around 310-330 nm in their UV-visible spectra. Six peaks were detected in the red varieties (Rosemary, Red Cardinal and Red Emmalie), comprising pelargonidin, peonidin, petunidin, malvidin and cyanidin derivatives, based on their molecular ions and characteristic fragments in the $\mathrm{MS}^{2}$ spectra. Peak 1r $\left([\mathrm{M}]^{+}\right.$at $m / z$ 887) was only detected in the Rosemary peel extract and was tentatively associated to a pelargonidin-3-O-p-coumaroylrutinoside5-O-glucoside isomer, based on the HPLC-DAD-MS results and previous literature reports (Kita et al., 2013; Oertel et al., 2017). Peak 2r ([M] ${ }^{+}$at
Table 3

Chromatographic properties, tentative identification, and quantification $(\mathrm{mg} / \mathrm{g}$ $\mathrm{dw}$ ) of the anthocyanins found in the studied red-skinned potato peels (mean \pm $\mathrm{SD})$.

\begin{tabular}{|c|c|c|c|c|c|}
\hline \multicolumn{6}{|c|}{ Identification } \\
\hline Peak & $\begin{array}{l}\text { Retention } \\
\text { time }\end{array}$ & $\begin{array}{l}\lambda_{\max } \\
(\mathrm{nm})\end{array}$ & $\begin{array}{l}{[\mathrm{M}]^{+}} \\
(\mathrm{m} / \mathrm{z})\end{array}$ & $\operatorname{MS}^{2}(m / z)$ & Tentative identification \\
\hline $1 \mathrm{r}$ & 34.87 & 504 & 887 & $\begin{array}{l}725 \\
(100), 433 \\
(5), 271(16)\end{array}$ & $\begin{array}{l}\text { Pelargonidin-3-O-p-cis- } \\
\text { coumaroylrutinoside-5- } \\
\text { O-glucoside }\end{array}$ \\
\hline $2 \mathbf{r}$ & 36.45 & 519 & 903 & $\begin{array}{l}449(100) \\
287(18)\end{array}$ & $\begin{array}{l}\text { Cyanidin 3-O-p- } \\
\text { coumaroylrutinoside-5- } \\
O \text {-glucoside }\end{array}$ \\
\hline $3 \mathbf{r}$ & 38.49 & 505 & 887 & $\begin{array}{l}725 \\
(100), 433 \\
(10), 271 \\
(13)\end{array}$ & $\begin{array}{l}\text { Pelargonidin-3-O-p-trans- } \\
\text { coumaroylrutinoside-5- } \\
\text { O-glucoside }\end{array}$ \\
\hline $4 r$ & 39.33 & 508 & 917 & $\begin{array}{l}755 \\
(100), 463 \\
(15), 301 \\
(38)\end{array}$ & $\begin{array}{l}\text { Peonidin-3-O-p- } \\
\text { coumaroylrutinoside-5- } \\
O \text {-glucoside }\end{array}$ \\
\hline $5 r$ & 39.8 & 517 & 947 & $\begin{array}{l}785 \\
(100), 493 \\
(19), 331 \\
(29)\end{array}$ & $\begin{array}{l}\text { Malvidin-3-O-p- } \\
\text { coumaroylrutinoside-5- } \\
O \text {-glucoside }\end{array}$ \\
\hline $6 r$ & 39.9 & 517 & 947 & $\begin{array}{l}785 \\
(100), 463 \\
(23), 301 \\
(38)\end{array}$ & $\begin{array}{l}\text { Peonidin-3-O- } \\
\text { feruloylrutinoside-5-O- } \\
\text { glucoside }\end{array}$ \\
\hline \multicolumn{6}{|c|}{ Quantification } \\
\hline Peak & \multicolumn{3}{|c|}{ Rosemary } & Red Cardinal & Red Emmalie \\
\hline $1 \mathrm{r}$ & \multicolumn{3}{|c|}{$0.0269 \pm 0.0005$} & nd & nd \\
\hline $2 \mathbf{r}$ & \multicolumn{3}{|c|}{$0.0474 \pm 0.0001^{\mathrm{a}}$} & $0.045 \pm 0.001^{\mathrm{b}}$ & $0.0437 \pm 0.0001^{c}$ \\
\hline $3 \mathbf{r}$ & \multicolumn{3}{|c|}{$0.2503 \pm 0.005^{\mathrm{a}}$} & $0.099 \pm 0.002^{\mathrm{b}}$ & $0.0581 \pm 0.0006^{\mathrm{d}}$ \\
\hline $4 r$ & \multicolumn{3}{|c|}{$0.248 \pm 0.004^{\mathrm{a}}$} & $0.226 \pm 0.001^{\mathrm{b}}$ & $0.212 \pm 0.0003^{c}$ \\
\hline $5 r$ & \multicolumn{3}{|c|}{ nd } & nd & $0.205 \pm 0.001$ \\
\hline $6 r$ & \multicolumn{3}{|l|}{ nd } & $0.2121 \pm 0.0003$ & nd \\
\hline TA & \multicolumn{3}{|c|}{$0.5722 \pm 0.0003^{\mathrm{b}}$} & $0.582 \pm 0.004^{\mathrm{a}}$ & $0.518 \pm 0.009^{c}$ \\
\hline
\end{tabular}

TA - Total Anthocyanins. nd - not detected. Standard calibration curves: pelargonidin-3-O-glucoside $\left(\mathrm{y}=276117 \mathrm{x}-480418, R^{2}=0.9979, \mathrm{LOD}=0.24\right.$ $\mu \mathrm{g} / \mathrm{mL}$ and $\mathrm{LOQ}=0.76 \mu \mathrm{g} / \mathrm{mL}$, peaks $1 \mathrm{r}$ and $3 \mathrm{r})$, cyanidin-3-O-glucoside $(\mathrm{y}=$ $243287 \mathrm{x}-1 \mathrm{E}+06, R^{2}=0.9986, \mathrm{LOD}=0.25 \mu \mathrm{g} / \mathrm{mL}$ and $\mathrm{LOQ}=0.83 \mu \mathrm{g} / \mathrm{mL}$, peak 2r), and peonidin-3-O-glucoside ( $\mathrm{y}=151438 \mathrm{x}-3 \mathrm{E}+06, R^{2}=0.9965$, $\mathrm{LOD}=0.13 \mu \mathrm{g} / \mathrm{mL}$ and LOQ $=0.40 \mu \mathrm{g} / \mathrm{mL}$, peaks $4 \mathrm{r}, 5 \mathrm{r}$, and $6 \mathrm{r}$ ). In each line, different Latin letters are significantly different according to Tukey's HSD test $(p$ $=0.05$ ), for each potato group peels.

$m / z$ 903), identified as a cyanidin derivative (cyanidin 3-O-p-coumaroylrutinoside-5-O-glucoside), was detected in all the red varieties, but not in the purple ones. Peak $3 \mathbf{r}\left([\mathrm{M}]^{+}\right.$at $m / z$ 887) was assigned as an isomer of Peak $1 \mathbf{r}$ and presented the highest concentration in the Rosemary peel extract. These two peaks might correspond to cis/trans pcoumaroyl isomers, as reported for similar anthocyanins present in grape and wine (Alcalde-Eon et al., 2006); cis isomers are expected to elute before the corresponding more common trans counterparts, which is coherent with the elution behaviour and levels of peaks $1 \mathbf{r}$ and $3 \mathbf{r}$ in the studied samples. Peaks 4r and 6r $\left([\mathrm{M}]^{+}\right.$at $\mathrm{m} / \mathrm{z} 917$ and 947, respectively) were identified as peonidin acyl-glycosides, with Peak $4 \mathbf{r}$ being the main compound detected in the Red Emmalie peels. Finally, Peak $5 \mathrm{r}\left([\mathrm{M}]^{+}\right.$at $m / z$ 947) was identified as an acylated malvidin glucoside (malvidin-3-O-p-coumaroylrutinoside-5-O-glucoside) detected only in the Red Emmalie peels. All the three red varieties showed very similar total anthocyanin concentration in the peels, ranging from 0.518 $\mathrm{mg} / \mathrm{g} \mathrm{dw}$ (Red Emmalie) to $0.583 \mathrm{mg} / \mathrm{g} \mathrm{dw}$ (Red Cardinal).

Regarding the purple varieties, seven peaks were detected, two of which were tentatively identified as petunidin derivatives (Peaks $\mathbf{1 p}$ and $\mathbf{2 p}$ ), two as peonidin derivatives (Peaks $\mathbf{4 p}$ and $\mathbf{6 p}$ ), two as malvidin derivatives (Peaks $\mathbf{5 p}$ and $\mathbf{7 p}$ ) and one as a pelargonidin derivative (Peak 3p). The molecular ions and fragmentation patterns of Peaks 1p 
Table 4

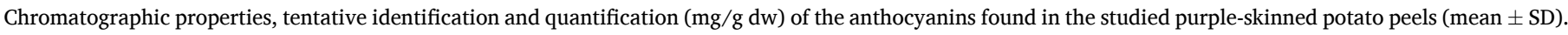

\begin{tabular}{|c|c|c|c|c|c|c|c|c|}
\hline \multicolumn{9}{|c|}{ Identification } \\
\hline Peak & Retention time & $\lambda_{\max }(\mathrm{nm})$ & {$[\mathrm{M}]^{+}(m / z)$} & $\operatorname{MS}^{2}(m / z)$ & & \multicolumn{3}{|c|}{ Tentative identification } \\
\hline $1 p$ & 36.77 & 531 & 933 & \multicolumn{2}{|c|}{$771(100), 479(24), 317(34)$} & \multicolumn{3}{|c|}{ Petunidin-3-O-p-coumaroylrutinoside-5-O-glucoside } \\
\hline $2 \mathbf{p}$ & 37.76 & 531 & 963 & \multicolumn{2}{|c|}{$801(100), 479(25), 317(38)$} & \multicolumn{3}{|c|}{ Petunidin-3-O-feruloylrutinoside-5- $O$-glucoside } \\
\hline $3 p$ & 38.59 & 507 & 887 & \multicolumn{2}{|c|}{$725(100), 433(10), 271(13)$} & \multicolumn{3}{|c|}{ Pelargonidin-3-O-p-coumaroylrutinoside-5-O-glucoside } \\
\hline $4 p$ & 39.03 & 520 & 917 & \multicolumn{2}{|c|}{$755(100), 463(15), 301(38)$} & \multicolumn{3}{|c|}{ Peonidin-3-O-p-coumaroylrutinoside-5-O-glucoside } \\
\hline $5 p$ & 39.21 & 532 & 947 & \multicolumn{2}{|c|}{$785(100), 493(19), 331(29)$} & \multicolumn{3}{|c|}{ Malvidin-3-O-p-coumaroylrutinoside-5-O-glucoside } \\
\hline $6 p$ & 39.82 & 522 & 947 & \multicolumn{2}{|c|}{$785(100), 463(23), 301(38)$} & \multicolumn{3}{|c|}{ Peonidin-3-O-feruloylrutinoside-5-O-glucoside } \\
\hline $7 \mathbf{p}$ & 39.95 & 532 & 977 & \multicolumn{2}{|c|}{$815(100), 493(15), 331(27)$} & \multicolumn{3}{|c|}{ Malvidin-3-O-feruloylrutinoside-5-O-glucoside } \\
\hline \multicolumn{9}{|c|}{ Quantification } \\
\hline Peak & Purple & Kefermarkter Blaue & UACH 0917 & Salad Blue & \multicolumn{2}{|c|}{ Blaue aus Finnland } & Shetland Black & Violetta \\
\hline $1 p$ & $0.843 \pm 0.001^{\mathrm{a}}$ & $0.65 \pm 0.01^{\mathrm{b}}$ & $0.282 \pm 0.004^{\mathrm{f}}$ & $0.66 \pm 0.004^{b}$ & \multicolumn{2}{|c|}{$0.59 \pm 0.007^{c}$} & $0.298 \pm 0.007^{\mathrm{e}}$ & $0.3952 \pm 0.004^{\mathrm{d}}$ \\
\hline $2 p$ & $0.233 \pm 0.005^{\mathrm{b}}$ & $0.168 \pm 0.002^{\mathrm{f}}$ & $0.0963 \pm 0.0001^{g}$ & $0.269 \pm 0.005^{\mathrm{a}}$ & \multicolumn{2}{|c|}{$0.172 \pm 0.001^{\mathrm{e}}$} & $0.205 \pm 0.002^{\mathrm{d}}$ & $0.2186 \pm 0.0001^{\mathrm{c}}$ \\
\hline $3 p$ & nd & nd & $0.0159 \pm 0.0002^{c}$ & nd & \multicolumn{2}{|c|}{ nd } & $0.0234 \pm 0.0004^{\mathrm{b}}$ & $0.0387 \pm 0.00002^{\mathrm{a}}$ \\
\hline $4 p$ & nd & nd & nd & nd & \multicolumn{2}{|l|}{ nd } & $0.241 \pm 0.005$ & nd \\
\hline $5 p$ & $0.171 \pm 0.001^{\mathrm{d}}$ & $0.1223 \pm 0.004^{\mathrm{e}}$ & $0.6559 \pm 0.001^{\mathrm{a}}$ & $0.2466 \pm 0.0001^{\mathrm{b}}$ & \multicolumn{2}{|c|}{$0.123 \pm 0.002^{\mathrm{e}}$} & nd & $0.211 \pm 0.001^{\mathrm{c}}$ \\
\hline $6 p$ & nd & nd & nd & nd & \multicolumn{2}{|c|}{ nd } & $0.2183 \pm 0.0002$ & nd \\
\hline $7 p$ & $0.119 \pm 0.003^{b}$ & $0.0937 \pm 0.0014^{d}$ & $0.2118 \pm 0.0058^{\mathrm{a}}$ & $0.212 \pm 0.001^{\mathrm{a}}$ & \multicolumn{2}{|c|}{$0.0985 \pm 0.0004^{c}$} & nd & nd \\
\hline TA & $1.368 \pm 0.001^{b}$ & $1.04 \pm 0.02^{\mathrm{d}}$ & $1.26 \pm 0.01^{\mathrm{c}}$ & $1.39 \pm 0.01^{\mathrm{a}}$ & \multicolumn{2}{|c|}{$0.98+0.01^{\mathrm{e}}$} & $0.99 \pm 0.02^{\mathrm{e}}$ & $0.863 \pm 0.005^{f}$ \\
\hline
\end{tabular}

TA - Total Anthocyanins. nd - not detected. Standard calibration curves: pelargonidin-3-O-glucoside $\left(\mathrm{y}=276117 \mathrm{x}-480418, R^{2}=0.9979, \mathrm{LOD}=0.24 \mu \mathrm{g} / \mathrm{mL}\right.$ and $\mathrm{LOQ}=0.76 \mu \mathrm{g} / \mathrm{mL}$, peak $3 \mathrm{p})$ and peonidin-3-O-glucoside $\left(\mathrm{y}=151438 \mathrm{x}-3 \mathrm{E}+06, R^{2}=0.9965, \mathrm{LOD}=0.13 \mu \mathrm{g} / \mathrm{mL}\right.$ and LOQ $=0.40 \mu \mathrm{g} / \mathrm{mL}, \mathrm{peaks} 1 \mathrm{p}, 2 \mathrm{p}, 4,5 \mathrm{p}, 6 \mathrm{p}$, and $7 \mathrm{p})$. In each lines different Latin letters are significantly different according to Tukey's HSD test $(p=0.05)$, for each potato group peels.

and $2 \mathbf{p}$ were coherent with derivatives of petunidin-3-O-rutinoside-5-Oglucoside acylated with $p$-coumaric and ferulic acids, respectively, as previously identified in coloured tubers of Solanum tuberosum (Kita et al., 2013). Peak 5p possessed the same molecular ion $[\mathrm{M}]^{+}$at $\mathrm{m} / \mathrm{z} 947$ as Peak 6p, but different fragmentation pattern. Two compounds with this molecular ion were also reported by Kita et al. (2013), identified as malvidin-3-O-p-coumaroylrutinoside-5-O-glucoside and peonidin-3-Oferuloylrutinoside-5-O-glucoside, respectively, although the second appeared only in the flesh of red tubers; those identities are coherent with the respective release of $\mathrm{MS}^{2}$ fragments at $m / z 331$ and 301 , corresponding to malvidin and peonidin aglycones. Petunidin-3-O-p-coumaroylrutinoside-5-O-glucoside (Peak 1p) was the main anthocyanin found in the peels of all the purple varieties, except for UACH 0917 for which malvidin-3-O-p-coumaroylrutinoside-5-O-glucoside (Peak 5p) was the main compound $(0.66 \mathrm{mg} / \mathrm{g} \mathrm{dw})$. The purple varieties showed a variable total anthocyanin content which ranged from $0.86 \mathrm{mg} / \mathrm{g} \mathrm{dw}$ (Violetta) to $1.39 \mathrm{mg} / \mathrm{g} \mathrm{dw}$ (Salad Blue).

Although potato peels are usually discarded, the present results suggest that these bio-residues could be used as sources of anthocyanins and other phenolic compounds. Yin et al. (2016) compared the flesh and peel of coloured potato varieties from China and found that on average the total anthocyanin contents in peels were 15.34 times higher than those of the respective flesh. Similarly, the total phenolic compounds content was 7.28 times higher in peels compared to the flesh. These results support the potential use of potato peels as sources of phenolic compounds with biological activity. However, despite the reports in the literature regarding the effect of pre- and post-harvest condition on colour parameters, it is important to note that the variability in the phenolic and anthocyanin profiles and contents of the peels herein found could be mainly attributed to inherited differences of the potato genotypes, as all samples were subjected to the same environmental factors (growing conditions, planting location and climate), transport and storage conditions, as well as the same extraction procedure.

\subsection{Bioactive properties}

\subsubsection{Cell-based antioxidant and anti-inflammatory activities}

The hydroethanolic extracts prepared from the tested potato peels were evaluated for their capacity to prevent lipid peroxidation of porcine brain tissues (TBARS assay) and haemolysis of sheep blood cells (OxHLIA assay). Additionally, the extracts' anti-inflammatory potential of inhibiting the growth of RAW 264.7 mouse macrophages was assessed. The results are presented in Table 5.

All the tested extracts were effective in diminishing the production of TBAR substances, however the recorded results varied greatly among varieties $\left(\mathrm{IC}_{50}=26-230 \mu \mathrm{g} / \mathrm{mL}\right.$ ). The peels from the Rosemary tubers presented the highest antioxidant capacity, as their extracts required the lowest concentration to diminish the lipid peroxidation in $50 \%$ compared to the control Trolox ( $\mathrm{IC}_{50}=26 \mu \mathrm{g} / \mathrm{mL}$ ), whereas Salad Blue presented the weakest activity $\mathrm{IC}_{50}$ with values being almost nine times lower than those of Rosemary cultivar $\left(\mathrm{IC}_{50}=230 \mu \mathrm{g} / \mathrm{mL}\right.$ ).

Regarding the OxHLIA assay, almost all the tested potato varieties presented positive results in retarding the erythrocytes haemolysis process ( $\Delta \mathrm{t}=60 \mathrm{~min}$ ), with the exception of Red Emmalie, that revealed no activity. Violetta and Purple were the varieties that presented the most prominent activity, as they recorded the lowest $\mathrm{IC}_{50}$ values $(16 \mu \mathrm{g} / \mathrm{mL}$ for both varieties). In agreement with the results herein found in the TBARS assay, Salad Blue peels also presented antioxidant activity in the OxHLIA assay $\left(\mathrm{IC}_{50}=294 \mu \mathrm{g} / \mathrm{mL}\right)$.

In agreement with our findings, several authors reported the antioxidant capacity of potato peel extracts in previous studies. For instance, positive results for antioxidant activity were obtained by the following assays: the 2,2-diphenyl-1-picryl- hydrazyl (DPPH) radical-scavenging capacity (Jeddou et al., 2018; Singh et al., 2011; Singh \& Rajini, 2004; Yin et al., 2016); reducing power (Jeddou et al., 2018; Singh \& Rajini, 2004), $\beta$-carotene bleaching inhibition activity (Jeddou et al., 2018), ABTS (2,2'-azino-bis(3-ethyl- benzothiazoline-6-sulfonic acid) radical scavenging activity (Jeddou et al., 2018), lipid peroxidation in rat liver homogenates (Singh \& Rajini, 2004) and iron ion chelation (Singh \& Rajini, 2004), all of which indicate the antioxidant potential of this bio-residue. In some studies, potato peel extracts also exerted significantly higher radical scavenging activity $(p<0.05)$ than the respective flesh extracts indicating the presence of higher contents of antioxidant compounds in this part of the tubers (Albishi, John, AlKhalifa, \& Shahidi, 2013; Wu et al., 2012).

Regarding the anti-inflammatory assay, Rosemary was the only variety that presented significant capacity to inhibit the growth of RAW 264.7 mouse macrophages ( $\mathrm{IC}_{50}=141 \mu \mathrm{g} / \mathrm{mL}$ ). It is important to mention that for the anti-inflammatory assay the maximum tested concentration of the extracts was $400 \mu \mathrm{g} / \mathrm{mL}$. In comparison with other studies, the Rosemary extract showed greater anti-inflammatory activity than, for example, $M$. jaboticaba epicarp $\left(\mathrm{IC}_{50}=299 \mu \mathrm{g} / \mathrm{mL}\right.$ ) 
Table 5

Antioxidant, anti-inflammatory and anti-proliferative activities and cytotoxicity ( $\mu \mathrm{g} / \mathrm{mL}$ extract) of the studied potato peels (mean \pm SD).

\begin{tabular}{|c|c|c|c|c|c|c|c|c|}
\hline \multirow[t]{2}{*}{ Potato varieties } & \multicolumn{2}{|c|}{$\begin{array}{l}\text { Antioxidant } \\
\text { (IC } 50 \text { values) }\end{array}$} & \multirow{2}{*}{$\begin{array}{l}\text { Anti-inflammatory } \\
\text { (IC }{ }_{50} \text { values) } \\
\text { RAW } 264.7\end{array}$} & \multicolumn{4}{|c|}{$\begin{array}{l}\text { Anti-proliferative } \\
\left(\mathrm{GI}_{50} \text { values }\right)\end{array}$} & \multirow{2}{*}{$\begin{array}{l}\text { Cytotoxicity } \\
\text { (GI } 50 \text { values) } \\
\text { PLP2 }\end{array}$} \\
\hline & TBARS & OxHLIA & & NCI-H460 & HepG2 & MCF-7 & HeLa & \\
\hline Rosemary & $26 \pm 3^{h}$ & $54 \pm 2^{c}$ & $141 \pm 6$ & $69 \pm 1^{\mathrm{e}}$ & $79 \pm 4^{\mathrm{f}}$ & $51 \pm 2^{\mathrm{f}}$ & $49 \pm 3^{f}$ & $304 \pm 9$ \\
\hline Red Cardinal & $187 \pm 12^{\mathrm{c}}$ & $123 \pm 7^{b}$ & $>400$ & $241 \pm 3^{c}$ & $305 \pm 11^{\mathrm{d}}$ & $315 \pm 10^{\mathrm{a}}$ & $333 \pm 17^{b}$ & $>400$ \\
\hline Rote Emmalie (Red Emmalie) & $46 \pm 2^{g}$ & n.a. & $>400$ & $248 \pm 6^{c}$ & $301 \pm 21^{\mathrm{d}}$ & $244 \pm 17^{c}$ & $227 \pm 11^{\mathrm{e}}$ & $>400$ \\
\hline Purple & $114 \pm 8^{\mathrm{f}}$ & $16 \pm 1^{\mathrm{c}, \mathrm{d}}$ & $>400$ & $268 \pm 17^{\mathrm{b}}$ & $365 \pm 18^{\mathrm{a}}$ & $188 \pm 11^{\mathrm{e}}$ & $330 \pm 2^{\mathrm{b}}$ & $>400$ \\
\hline Kefermarkter Blaue & $208 \pm 12^{\mathrm{b}}$ & $32 \pm 2^{c, d}$ & $>400$ & $217 \pm 12^{\mathrm{d}}$ & $302 \pm 9^{\mathrm{d}}$ & $279 \pm 12^{\mathrm{b}}$ & $313 \pm 33^{c}$ & $>400$ \\
\hline UACH 0917 & $127 \pm 7^{\mathrm{e}}$ & $24 \pm 2^{\mathrm{c}, \mathrm{d}}$ & $>400$ & $280 \pm 7^{\mathrm{a}}$ & $319 \pm 1^{\mathrm{c}}$ & $224 \pm 10^{\mathrm{d}}$ & $346 \pm 10^{\mathrm{a}}$ & $>400$ \\
\hline Salad Blue & $230 \pm 6^{\mathrm{a}}$ & $294 \pm 8^{\mathrm{a}}$ & $>400$ & $281 \pm 6^{\mathrm{a}}$ & $286 \pm 12^{\mathrm{e}}$ & $215 \pm 12^{\mathrm{d}}$ & $292 \pm 19^{d}$ & $>400$ \\
\hline Blaue aus Finnland & $154 \pm 2^{\mathrm{d}}$ & $122 \pm 4^{\mathrm{b}}$ & $>400$ & $276 \pm 2^{\mathrm{a}, \mathrm{b}}$ & $281 \pm 10^{\mathrm{e}}$ & $281 \pm 66^{\mathrm{b}}$ & $333 \pm 12^{\mathrm{b}}$ & $>400$ \\
\hline Shetland Black & $190 \pm 6^{c}$ & $53 \pm 2^{c}$ & $>400$ & $269 \pm 11^{b}$ & $343 \pm 9^{b}$ & $210 \pm 10^{\mathrm{d}}$ & $233 \pm 3^{\mathrm{e}}$ & $>400$ \\
\hline Violetta (Blaue Elise) & $144 \pm 5^{\mathrm{d}}$ & $16 \pm 1^{\mathrm{c}, \mathrm{d}}$ & $>400$ & $271 \pm 19^{\mathrm{b}}$ & $317 \pm 11^{\mathrm{c}}$ & $216 \pm 17^{d}$ & $335 \pm 11^{\mathrm{a}, \mathrm{b}}$ & $>400$ \\
\hline
\end{tabular}

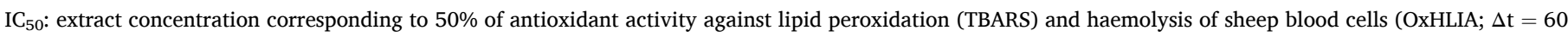

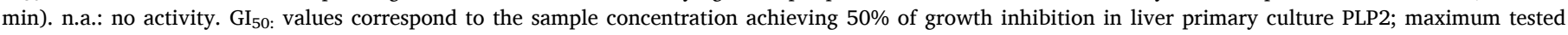

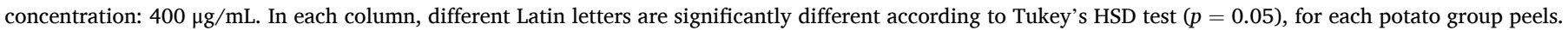

(Albuquerque et al., 2020). Moreover, Wahyudi et al. (2020) demonstrated the anti-inflammatory properties of potato peel extracts by conducting an in vivo study with rats, using carrageenan-induced paw edema and diclofenac as the reference drug. Their results showed that, compared with the negative control (distilled water), treatment doses of $100 \mathrm{mg} / \mathrm{kg}, 200 \mathrm{mg} / \mathrm{kg}$, and $400 \mathrm{mg} / \mathrm{kg}$ significantly reduced the edema volume increment.

\subsubsection{Anti-proliferative activity and cytotoxicity}

The in vitro anti-proliferative properties of the coloured potato peels were also investigated and the corresponding results are presented in Table 5. Additionally, a cytotoxicity assay was carried out to assess the safety of the extracts for incorporation into food formulations. Considering that potato peels may be rich in potentially toxic compounds such as glycoalkaloids (Friedman, Roitman, \& Kozukue, 2003; Hossain et al., 2015; Sotelo \& Serrano, 2000), this test is essential prior to suggesting the use of peel extracts for food purposes.

The inclusion of phytochemicals and functional foods in the diet has been proposed as a way of preventing the development of cancer cells (Albuquerque et al., 2020). In the present work, the capacity of the studied potato peels in inhibiting tumour cell growth was evaluated in four tumour cell lines. All the studied hydroethanolic extracts revealed anti-proliferative activity against all the tested tumour cell lines, with $\mathrm{GI}_{50}$ values ranging from $69 \mu \mathrm{g} / \mathrm{mL}$ to $281 \mu \mathrm{g} / \mathrm{mL}$ for NCI-H460 (nonsmall cell lung carcinoma) cells, $79 \mu \mathrm{g} / \mathrm{mL}$ to $365 \mu \mathrm{g} / \mathrm{mL}$ for HepG2 (hepatocellular carcinoma) cells, $51 \mu \mathrm{g} / \mathrm{mL}$ to $315 \mu \mathrm{g} / \mathrm{mL}$ for MCF-7 (breast carcinoma) cells and $49 \mu \mathrm{g} / \mathrm{mL}$ to $346 \mu \mathrm{g} / \mathrm{mL}$ for HeLa (cervical carcinoma) cells. The extract from the Rosemary variety presented the highest anti-proliferative capacity for all the tested tumour cell lines, as it required the lowest concentrations to present activity in comparison with the other nine varieties. For comparison, Albuquerque et al. (2020) reported $\mathrm{GI}_{50}$ values within the ranges found herein for the antiproliferative activity of $M$. jaboticaba epicarp against three tumor cell lines $(\mathrm{HepG} 2=258 \mu \mathrm{g} / \mathrm{mL}$; MCF-7 = $300 \mu \mathrm{g} / \mathrm{mL} ; \mathrm{HeLa}=278 \mu \mathrm{g} / \mathrm{mL}$; NCI-H460 $>400 \mu \mathrm{g} / \mathrm{mL}$ ). Moreover, Reddivari, Vanamala, Chintharlapalli, Safe, \& Miller (2007) also found that the anthocyanin fraction from potato extracts exhibited anticancer properties, being cytotoxic to prostate cancer cells through the activation of caspase-dependent and caspase-independent pathways.

In order to assess the safety of the tested extracts, porcine liver was used as a model to study the hepatotoxicity effects of the extracts, due to its similarity with the human liver in terms of cellular and physiological functioning (Corrêa et al., 2018). The results showed that the extracts did not reveal toxicity for PLP2 cells up to the maximum tested concentration $\left(\mathrm{GI}_{50}\right.$ value $>400 \mu \mathrm{g} / \mathrm{mL}$ ), with the exception of the Rosemary extract. Nevertheless, the cytotoxic effect of this variety was recorded for a high concentration of the extract $\left(\mathrm{GI}_{50}\right.$ value $=304 \mu \mathrm{g} / \mathrm{mL}$ ) indicating low cytotoxic effects. This finding highlights the safety of potato peel extracts to be used as natural additives in food formulations in low concentrations which may exert antioxidant activity without cytotoxic effects to non-tumor cell lines.

\section{Conclusion}

The potato peels herein studied contained non-anthocyanin and anthocyanin phenolic compounds. Caffeic and caffeoylquinic acid were found in the highest concentrations among non-anthocyanin phenolics in all the samples, while $O$-glycosylated flavonoid derivatives and polyamine derivatives were also detected. Regarding anthocyanins, all the tentatively identified compounds were acylated with a hydroxycinnamic acidIn the red-skinned varieties, pelargonidin-3-p-coumaroylrutinoside-5-glucoside isomer, peonidin-3-p-coumaroylrutinoside-5glucoside, and malvidin-3-p-coumaroylrutinoside-5-glucoside presented the highest content; while in the purple-skinned varieties, petunidin-3-pcoumaroylrutinoside-5-glucoside was the most abundant compound. Positive results for the antioxidant capacity were recorded in the extracts of all the assayed potato peels, as well as significant antitumor activity. Particularly, the peels from the red-skinned variety Rosemary presented the best antioxidant and antitumor results and were the only to reveal anti-inflammatory activity. The studied potato peels also showed no hepatotoxic effects up to the maximum tested concentration of extract $(400 \mu \mathrm{g} / \mathrm{mL})$, except for the Rosemary peels that showed toxicity for concentrations above $304 \mu \mathrm{g} / \mathrm{mL}$. In conclusion, the present results would support the use of potato peels as valuable sources of bioactive compounds and as natural additives in functional food formulations. However, further studies with more varieties are needed to reveal the genotypic variability, as well as to identify the effect of preand post-harvest factors on bioactive compounds content and bioactivities of potato processing bio-residues.

\section{CRediT authorship contribution statement}

Shirley L. Sampaio: Methodology, Investigation, Writing - original draft. Spyridon A. Petropoulos: Conceptualization, Writing - original draft. Maria Inês Dias: Methodology, Investigation, Writing - review \& editing. Carla Pereira: Methodology, Investigation. Ricardo C. Calhelha: Methodology, Investigation. Ângela Fernandes: Methodology, Investigation. Camila M.M. Leme: Methodology, Investigation. Alexios Alexopoulos: Methodology, Investigation. Celestino Santos-Buelga: Conceptualization, Methodology, Writing - review \& editing. Isabel C.F. R. Ferreira: Conceptualization, Methodology, Writing - review \& editing. Lillian Barros: Funding acquisition, Conceptualization, Methodology, Writing - review \& editing. 


\section{Declaration of Competing Interest}

The authors declare that they have no known competing financial interests or personal relationships that could have appeared to influence the work reported in this paper.

\section{Acknowledgements}

The authors are grateful to the Foundation for Science and Technology (FCT, Portugal) for financial support by national funds FCT/ MCTES to CIMO (UIDB/00690/2020); the national funding by FCT, P.I., through the institutional scientific employment program-contract for $\mathrm{L}$. Barros, Maria Inês Dias and C. Pereira contracts; to FEDER-Interreg España-Portugal programme through the project TRANSCoLAB 0612_TRANS_CO_LAB_2_P; to the European Regional Development Fund (ERDF) through the Regional Operational Program North 2020, within the scope of Project Mobilizador Norte-01-0247-FEDER-024479: ValorNatural ${ }^{\circledR}$; and also to the Ministry of Education, Science and Technological Development of Republic of Serbia (451-03-68/2020-14/ 200007). GIP-USAL is financially supported by the Spanish Government through the project AGL2015-64522-C2-2-R. S. Sampaio acknowledges CAPES Foundation (Ministry of Education, Brazil) for her PhD grant no. 99999.001423/2015-00.

\section{References}

Adamo, P., Zampella, M., Quétel, C. R., Aversano, R., Dal Piaz, F., De Tommasi, N., Carputo, D. (2012). Biological and geochemical markers of the geographical origin and genetic identity of potatoes. Journal of Geochemical Exploration, 121, 62-68.

Albishi, T., John, J. A., Al-Khalifa, A. S., \& Shahidi, F. (2013). Phenolic content and antioxidant activities of selected potato varieties and their processing by-products. Journal of Functional Foods, 5(2), 590-600.

Albuquerque, B. R., Pereira, C., Calhelha, R. C., José Alves, M., Abreu, R. M. V., Barros, L., ... Ferreira, I. C. F. R. (2020). Jabuticaba residues (Myrciaria jaboticaba (Vell.) Berg) are rich sources of valuable compounds with bioactive properties. Food Chemistry, 309, Article 125735.

Alcalde-Eon, C., Escribano-Bailón, M. T., Santos-Buelga, C., \& Rivas-Gonzalo, J. C. (2006). Changes in the detailed pigment composition of red wine during maturity and ageing: A comprehensive study. Analytica Chimica Acta, 563, 238-254.

Barros, L., Dueñas, M., Dias, M. I., Sousa, M. J., Santos-Buelga, C., \& Ferreira, I. C. F. R. (2013). Phenolic profiles of cultivated, in vitro cultured and commercial samples of Melissa officinalis L. infusions. Food Chemistry, 136(1), 1-8.

Barros, L., Pereira, E., Calhelha, R. C., Dueñas, M., Carvalho, A. M., Santos-Buelga, C., \& Ferreira, I. C. F. R. (2013). Bioactivity and chemical characterization in hydrophilic and lipophilic compounds of Chenopodium ambrosioides L. Journal of Functional Foods, $5,1732-1740$.

Cabezas-serrano, A. B., Amodio, M. L., Cornacchia, R., Rinaldi, R., \& Colelli, G. (2009). Suitability of five different potato cultivars (Solanum tuberosum L.) to be processed as fresh-cut products. Postharvest Biology and Technology, 53, 138-144.

Camire, M. E., Kubow, S., \& Donelly, D. J. (2009). Potatoes and human health. Critical Reviews in Food Science and Nutrition, 49, 823-840.

Chaves-Silva, S., dos Santos, A. L., Chalfun-Júnior, A., Zhao, J., Peres, L. E. P., \& Benedito, V. A. (2018). Understanding the genetic regulation of anthocyanin biosynthesis in plants - Tools for breeding purple varieties of fruits and vegetables. Phytochemistry, 153, 11-27.

Choi, S. H., Kozukue, N., Kim, H. J., \& Friedman, M. (2016). Analysis of protein amino acids, non-protein amino acids and metabolites, dietary protein, glucose, fructose, sucrose, phenolic, and flavonoid content and antioxidative properties of potato tubers, peels, and cortexes (pulps). Journal of Food Composition and Analysis, 50, $77-87$.

Corrêa, R. C. G., Barros, L., Fernandes, Â., Sokovic, M., Peralta, R. M., Brachtc, A., \& Ferreira, I. C. F. R. (2018). A natural food ingredient based on ergosterol: Optimization of the extraction from Agaricus blazei, evaluation of bioactive properties and incorporation in yogurts. Food and Function, 9(3), 1465-1474.

Corrêa, R. C. G., De Souza, A. H. P., Calhelha, R. C., Barros, L., Glamoclija, J., Sokovic, M., ... Ferreira, I. C. F. R. (2015). Bioactive formulations prepared from fruiting bodies and submerged culture mycelia of the Brazilian edible mushroom Pleurotus ostreatoroseus Singer. Food and Function, 6(7), 2155-2164.

Friedman, M., Kozukue, N., Kim, H., Choi, S., \& Mizuno, M. (2017). Glycoalkaloid, phenolic, and flavonoid content and antioxidative activities of conventional nonorganic and organic potato peel powders from commercial gold, red, and Russet potatoes. Journal of Food Composition and Analysis, 62, 69-75.

Friedman, M., Roitman, J. N., \& Kozukue, N. (2003). Glycoalkaloid and Calystegine Contents of Eight Potato Cultivars. Journal of Agricultural and Food Chemistry, 51(10).

Garcia, J. A. A., Corrêa, R. C. G., Barros, L., Pereira, C., Abreu, R. M. V., \& Ferreira, I. C. F. R. (2019). Chemical composition and biological activities of Juçara
(Euterpe edulis Martius) fruit by-products, a promising underexploited source of highadded value compounds. Journal of Functional Foods, 55, 325-332.

Hossain, M. B., Rawson, A., Aguiló-aguayo, I., Brunton, N. P., \& Rai, D. K. (2015) Recovery of Steroidal Alkaloids from Potato Peels Using Pressurized Liquid Extraction. Molecules, 20, 8560-8573.

Jeddou, K. B., Bouaziz, F., Boisset, C., Nouri-ellouz, O., Maktouf, S., Ellouz-chaabouni, S., \& Ellouz-ghorbel, R. (2018). Structural, functional, and biological properties of potato peel oligosaccharides. International Journal of Biological Macromolecules, 112, $1146-1155$.

Juneja, V. K., Friedman, M., Mohr, T. B., Silverman, M., \& Mukhopadhyay, S. (2018). Control of Bacillus cereus spore germination and outgrowth in cooked rice during chilling by nonorganic and organic apple, orange, and potato peel powders. Journal of Food Processing and Preservation, 42, 1-7.

Kita, A., Bakowska-Barczak, A., Hamouz, K., Kułakowska, K., \& Lisińska, G. (2013). The effect of frying on anthocyanin stability and antioxidant activity of crisps from redand purple-fleshed potatoes (Solanum tuberosum L.). Journal of Food Composition and Analysis, 32(2), 169-175.

Oertel, A., Matros, A., Hartmann, A., Arapitsas, P., Dehmer, K. J., Martens, S., \& Mock, H.-P. (2017). Metabolite profiling of red and blue potatoes revealed cultivar and tissue specific patterns for anthocyanins and other polyphenols. Planta, 246(2), $281-297$.

Pathak, P. D., Mandavgane, S. A., Puranik, N. M., Jambhulkar, J., \& Kulkarni, B. D. (2018). Valorization of potato peel: A biorefinery approach. Critical Reviews in Biotechnology, 218-230.

Ponasik, J. A., Strickland, C., Faerman, C., Savvides, S., Karplus, P. A., \& Ganem, B. (1995). Kukoamine A and other hydrophobic acylpolyamines: Potent and selective inhibitors of Crithidia fasciculata trypanothione reductase. Biochemical Journal, 311 (2), 371-375.

Reddivari, L., Vanamala, J., Chintharlapalli, S., Safe, S. H., \& Miller, J. C. (2007). Anthocyanin fraction from potato extracts is cytotoxic to prostate cancer cells through activation of caspase-dependent and caspase-independent pathways. Carcinogenesis, 28(10), 2227-2235.

Rommens, C. M., Richael, C. M., Yan, H., Navarre, D. A., Ye, J., Krucker, M., \& Swords, K. (2008). Engineered native pathways for high kaempferol and caffeoylquinate production in potato. Plant Biotechnology Journal, 6(9), 870-886.

Sampaio, S. L., Fernandes, A., Pereira, C., Calhelha, R. C., Sokovic, M., Santos-Buelga, C., . Ferreira, I. C. F. R. (2020). Nutritional value, physicochemical characterization and bioactive properties of Brazilian quinoa BRS Piabiru. Food \& Function, 11, 2969-2977.

Sampaio, S. L., Petropoulos, S. A., Alexopoulos, A., Heleno, S. A., Santos-Buelga, C., Barros, L., \& Ferreira, I. C. F. R. (2020). Potato peels as sources of functional compounds for the food industry: A review. Trends in Food Science and Technology, 103, 118-129.

Schieber, A., Stintzing, F. C., \& Carle, R. (2002). By-products of plant food processing as a source of functional compounds - recent developments. Trends in Food Science \& Technology, 12(2001), 401-413.

Seijo-Rodríguez, A., Escuredo, O., Rodríguez-Flores, M. S., \& Seijo-Coello, M. C. (2018). Assessment of Antioxidant Potential of Potato Varieties and the Relationship to Chemical and Colorimetric Measurements. American Journal of Potato Research, 95 (1), 71-78.

Singh, A., Sabally, K., Kubow, S., Donnelly, D. J., Gariepy, Y., Orsat, V., \& Raghavan, G. S. V. (2011). Microwave-Assisted Extraction of Phenolic Antioxidants from Potato Peels. Molecules, 16, 2218-2232.

Singh, N., \& Rajini, P. S. (2004). Free radical scavenging activity of an aqueous extract of potato peel. Food Chemistry, 85, 611-616.

Sotelo, A., \& Serrano, B. (2000). High-performance liquid chromatographic determination of the glycoalkaloids $\alpha$-solanine and $\alpha$-chaconine in 12 commercial varieties of Mexican potato. Journal of Agricultural and Food Chemistry, 48(6), 2472-2475.

Su, X., Xu, J., Rhodes, D., Shen, Y., Song, W., Katz, B., ... Wang, W. (2016). Identification and quantification of anthocyanins in transgenic purple tomato. Food Chemistry, 202, 184-188.

Svobodova, B., Barros, L., Sopik, T., Calhelha, R. C., Heleno, S., Alves, M. J., Ferreira, I. C. F. R. (2017). Non-edible parts of Solanum stramoniifolium Jacq.-a new potent source of bioactive extracts rich in phenolic compounds for functional foods. Food and Function, 8(5), 2013-2021.

Torres, M. D., Fradinho, P., Rodríguez, P., Falqué, E., Santos, V., \& Domínguez, H. (2020). Biorefinery concept for discarded potatoes: Recovery of starch and bioactive compounds. Journal of Food Engineering, 275, Article 109886.

Wahyudi, I. A., Ramadhan, F. R., Wijaya, R. I. K., Ardhani, R., \& Utami, T. W. (2020). Analgesic, anti-inflammatory and anti-biofilm-forming activity of potato (Solanum tuberosum L.) peel extract. Indonesian Journal of Cancer Chemoprevention, 11(1), 30.

Wu, Z., Xu, H., Ma, Q., Cao, Y., Ma, J., \& Ma, C. (2012). Isolation, identification and quantification of unsaturated fatty acids, amides, phenolic compounds and glycoalkaloids from potato peel. Food Chemistry, 135(4), 2425-2429.

Yang, S. T., Wu, X., Rui, W., Guo, J., \& Feng, Y. F. (2015). UPLC/Q-TOF-MS analysis for identification of hydrophilic phenolics and lipophilic diterpenoids from Radix Salviae Miltiorrhizae. Acta Chromatographica, 27(4), 711-728.

Yang, Y., \& Achaerandio, I. (2015). Classification of potato cultivars to establish their processing aptitude. Journal of the Science of Food Agriculture, 96, 413-421.

Yin, L., Chen, T., Li, Y., Fu, S., Xu, M., \& Niu, Y. (2016). A comparative study on total anthocyanin content, composition of anthocyanidin, total phenolic content and antioxidant activity of pigmented potato peel and flesh. Food Science and Technology Research, 22(2), 219-226. 